\title{
Bankruptcy Prediction of the Banking Sector Using Bankometer: Comparative Study Based On CompanySize
}

\author{
Felita Bella ${ }^{1,}$ Wirawan ED Radianto ${ }^{2 *}$ \\ ${ }^{1}$ Universitas Ciputra, CitraLand CBD Boulevard, Surabaya, Indonesia \\ ${ }^{2}$ Universitas Ciputra, CitraLand CBD Boulevard, Surabaya, Indonesia \\ "Corresponding author. Email: wirawan@ @iputra.ac.id
}

\begin{abstract}
This study aims to investigate bankruptcy predictions with the banking sector using a bankometer. This study compares bankruptcy predictions between large, medium and small banks based on its market capitalization on the emerging stock market namely Indonesia Stock Exchange. The research data was obtained from financial reports between 2010-2018 from the sample banks. The results indicate that there are differences in bankruptcy predictions between large small banks and between medium and small banks. But there is no difference in bankruptcy predictions between large and medium banks. Furthermore, the results show that small banks have the smallest average bankruptcy predictions and large banks have the largest average bankruptcy predictions.
\end{abstract}

Keywords: Bankometer, Company size, Financial Distress.

\section{INTRODUCTION}

Banks are one of the institutions that play an important role in a country's economy cycle, including Indonesia. Hence, bank failures can cause a disruption to the country's economy condition [1]. In result, it is necessary to identify the possibility of bank bankruptcyas early as possible as it may result in disruption of the country's economy and further impact the society at large. Bankruptcy itself is a condition where a company that is no longer able to operate its company properly due to a critical financial issue [2]. Financial difficulties are marked by the uncertainty of the company's profitability and will usually be an early indicator of company bankruptcy [3]. To minimize theimpact of bank failures, we need a system that can indicate early warnings of financial problems faced bybanks. One way to predict bankruptcy is to analyze the company's financial statements. With the analysis of financial statements, the management team can find outits financial position and can quickly determine the next strategies that they should take to avoid the state of bankruptcy.

There are several methods that can be used to predict bankruptcy, but the researchers choose to use the Bankometer S- score method because its elements are specificallly tailored to the banking industry. The Bankometer S- score method is a method developed based on International Monetary Fund recommendations [4]. This method is also easier to be use and is more accurate. In addition, the process of developing this model is in accordance with the conditions of the banking system so that it can better illustrate the performance of a bank. This method is also used by a number of researchers to predict bankruptcy in the banking sector $[5,6,7]$.

One of the most important factors to explore company performance is the company size [8]. A company that has a large market capitalization will have an impact on the company and will be more well-known 
to the public. The more the company is known by the public, the higher stock price will increase so that the company gets capital gains and build a positive company's image. That way the company will have an easier way to get funds. In addition, the market's confidence in the company will also increase. In other words, people in the society are more likely to trust a company with larger capitalization because they belive that the company is able to provide benefits and have future prospects. Company size is also a scale to classify a company into big, medium or small categories. The size of a company can be expressed by various proxies including assets, sales and market capitalization [9].

The urgency of this research is to see the relationship between bankruptcy predictions viewed from the capitalization of the bank. This is different from pasts researches which only calculate predictions per bankruptcy $[5,7,8$,$] . This study aims not only to calculate$ bankruptcy predictions, but also to compare bankruptcy predictions between banks with large, medium and small capitalization. In addition, this study also aims to investigate differences in bankruptcy predictions of banks listed on the Indonesia Stock Exchange (IDX) using the Bankometer S-Score.

\section{LITERATURE REVIEW}

The Bankometer S- score model is a model used for evaluating the soundness of a bank with the Solvency (Sscore) parameter developed based on the IMF recommendations [10]. Bankometer $S$ - score is a comprehensive procedure developed based on the author's initiative which makes the IMF recommendations (2000) as the basis for developing the model. The S- score bankometer was developed to measure vulnerability in financial institutions and is better than other models such as the Altman Z- score because the model is adjusted for the banking industry. This model was developed to improve bank's performance and soundness, and it is hoped that this model can help the internal management team to avoid bankruptcy. This model is expected to help potential investors, account holders and bank management in making decisions and controlling the financial system to avoid the possibility of future financial crises. The Bankometer S- score method can be used to compare two different types of banks, namely Islamic and Conventional Banks in Indonesia, private banks, and public banks [11, 12].

We use Signaling theory in this research. Signaling theory emphasizes the importance of information released by company to support external parties' decision to make an investment on the company. Signal is an action taken by the company to give hints to the investors about how the management team sees the company's prospects [13]. This is very important because the information basically covers descriptions, notes or a picture of the company's past and future conditions for the survival of a company. It is important for the management team to report and disclose the state of their financial stability to external parties because it will affect investors" decision making. Theresults of this study, in regard to bank bankruptcy predictions, can be used as a signal to external parties both investors and customers about how the company'scondition looks like and what is the differences in bankruptcy predictions between large, medium and small banks. Furthermore, the result of this study can be used as a differentiator between banks with strong and weak financial prospect.

Bankruptcy will occur more quickly in a country that is experiencing economic hardship, which will trigger bankruptcy in companies that are already not in a stable financial state. Companies that are in a good position may also experience difficulties in meeting funds for operational activities caused by the country's economic crisis (Winny and Luciana, 2005). Internal bank failures can be caused by giving customers too much credits, causing payment arrears until finally unable to pay, inefficient management caused by lack of ability, skills, experience, attitude of initiative from the management team as well as abuse of authority and fraud both by employees and top managers, especially when dealing with bank finance [15].

Bankruptcy predictions are known by several terms including financial difficulties, financial risk, bad credit and failure predictions [16]. The reason a company goes bankrupt is because of financial problems, fraud, disaster, negligence or economic problems [17]. Individuals who understand the importance of positive social interaction for themselves show individuals who have the cognitive where individuals' cognitive is an important social capital for the economy [18]. Humans are viewed as the creators of objective social reality through an externalization process, just as objective reality influences people through the internalization process

\section{Hypothesis Development}

The indicators that imply a company is going bankrupt are declining in profitability, declining in market position, ability to pay off bad liabilities, high employee turnover or low morale, decrease in sales volume and value, dependence on debt and loss in operations. The more the company is known by the public, the higher stock price will increase so that the company gets capital gains and build a positive company's image. In addition, the market's confidence in the company will also increase. The more activities that the banks have; the higher the risks that the banks will face; it can be said that the possibility of bankruptcy is 
also higher. The greater the bank, the greater the managerial inefficiency will occur [19].

$\mathrm{H} 1=$ There are differences in ban kruptcy predictions between large, medium and small size banks in Indonesia.

\begin{tabular}{|c|c|}
\hline Variable & Sources \\
\hline \multirow{2}{*}{$\begin{array}{l}\text { CA }=\frac{\text { Core Cap } \text { tal }}{\text { Total assets }} \\
\text { CD }-\underline{\text { T(er } 1 \text { cap }(t a l / T(\text { er } 0 \text { cap }(t a l}\end{array}$} & $\begin{array}{l}\text { Nan-kuang } \\
(2001)\end{array}$ \\
\hline & \\
\hline$R(s k 3 e(45$ ted assets & Laely (2018) \\
\hline \multicolumn{2}{|l|}{$\mathrm{EA}=\stackrel{E q u(t y)}{-}$} \\
\hline $\mathrm{EA}=$ Total assets & Laely (2018) \\
\hline NPI $=\frac{\text { Non per }=\text { orm }(n 4 \text { loan } 4 \text { ross }}{\text { Total loan }}$ & $\begin{array}{l}\text { Nova et al. } \\
(2016)\end{array}$ \\
\hline 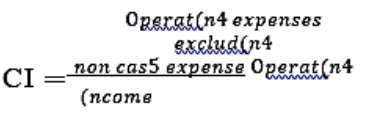 & $\begin{array}{l}\text { Nagmani } \\
\text { andAbirami(2017) }\end{array}$ \\
\hline $\mathrm{T} . \mathrm{A}=\frac{\text { Loan }}{\text { Total Assets }}$ & Laely (2018) \\
\hline
\end{tabular}

\section{METHOD}

The population group of this research includes 45 banking sector companies listed on the Stock Exchange. This study uses a purposive sampling method within the criteria of banking sector companies listed on the IDX, banking sector companies that publish annual financial statements for the period of 2010-2018, and companies that use the fiscal in December. Researchers use data pooling, which is obtained from company data listed on the IDX and within the period 2010-2018 [20].

he size of the company is indicated by the company's market capitalization. The success of a company in utilizing managed resources can be seen through capitalization. The greater the market capitalizationvalue of a company shows the easier it is for companies to get working capital in the form of funding. Market capitalization provides an illustration for investors about the strength of a company that encourages investor interest to include the company's shares in its portfolio [23].

Market capitalization is divided into 3 groups: large capitalization (big-cap), medium capitalization (midcap) and small capitalization (small-cap) [24]. Companies with large capitalization are companies that have a market capitalization of greater or equal to Rp. 5 trillion. Companies with medium capitalization are companies that have a market capitalization of greater or equal to Rp. 1 trillion to less than Rp. 5 trillion. While companies with small market capitalization are companies that have a capitalization of less than Rp. 1 trillion [25]. This study Kruskal Wallis test which is an alternative to the One Way ANOVA test [26].

\section{RESULT AND DISCUSSION}

Data used in this study is secondary data which are annual reports of banking institutions registered in the IDX using data form year 2010-2018 with total of 45 companies which were then categorized into 3 groups, which are big, medium and small. The size of the company is determined based on the market capitalization of the company, if the company hasmarket capitalization of greater than or Rp. 5 trillion then it will be categorized as big company. Companies with medium market capitalization are those with market capitalization greater than or equal to Rp. 1 trillion up to less than Rp. 5 trillion and companies are categorized as having small market capitalization if the company has market capitalization less than Rp. 1trillion.

Descriptive statistics measurements were conducted toillustrate the phenomena or characteristics of the data. Below is the output of the Bankometer S-score descriptive statistive analaysis result for big, medium and small categories:

Table 2. Descriptive Stats of Bankometer S-score

\begin{tabular}{lcrrrrr}
\hline & \multicolumn{3}{c}{ Min. } & Max & Mean & Std. Dev. \\
\cline { 2 - 5 } Big Bank & $\mathbf{N}$ & $\overline{94}$ & 269 & 145,71 & 28,715 \\
Medium Bank & 150 & & 95 & 456 & 157,16 & 55,041 \\
Small Bank & 39 & & 121 & 379 & 179,89 & 54,537 \\
S-score & 372 & 94 & 456 & 153,91 & 45,104 \\
\hline
\end{tabular}

In table 2 it can be seen that overall the minimum value of bankometer S-score is 94 , which belongs to a big bank. Maximum value overall is 456 , which belongs to a medium bank. This shows that all banks are predicted to be in good condition as they are above the limit of 70 . The average bankometer S-score for big banks is

145.71 with standard deviation of 28.715 , which means that the average for big banks is below the overall average bankometer $\mathrm{S}$-score. The average bankometer $\mathrm{S}$ score for medium banks is 157.16 with standard deviation of 55.041, which means that the average for medium banks is above the overall average bankometer $\mathrm{S}$ score. In small category the average bankometer S- score is 179.89 with standard deviation of 54.537 which means that the average for small banks is above the overall average bankometer S-score. The highest bankometer Sscore average is in small banks, followed by medium banks then big banks. This shows that small banks have the smallest bankruptcy prediction average due to having highest bankometer S-score average and big banks have the highest bankruptcy prediction average due to having the lowestbankometer S-score. 
Table 3. Mann Whitney Test

\begin{tabular}{lc}
\hline Company Size & Asymp. Sig. (2-tailed) \\
\hline Big - Medium & 0,386 \\
Big - Small & 0,000 \\
Medium - Small & 0,000 \\
\hline
\end{tabular}

Based on table 3 it can be seen that big banksmediumbanks have the asymp. sig value of $0.386>0.05$ therefore it can be concluded that there is nosignificance difference between bankruptcy prediction of big banks and medium banks. For big and small banks the asymp. sig value is $0.000<0.05$, therefore it can be concluded that there is significant difference between the bankruptcy prediction of big banks and small banks. Similarly for medium banks and small banks, the asymp. sig value is $0.000<0.05$, therefore it can be concluded that there is significant difference between the bankruptcy predictions of medium banks and small banks. Bankometer model shows that there is no public bank registered in the IDX that is predicted to go bankrupt. Overall the banks have score above the standard limit of $70 \%$ which means that in the past 10 years the banks in Indonesia are in good conditions and have strong financial positions over the period of 20102018. In the average difference tests conducted between the three categories, which are big, medium and small size, it shows that there is significant differences between bankruptcy predictions of big, medium and small banks. However, in the average tests between two categories only big banks and small banks and medium banks and small banks have the significant difference. There was not significant difference in bankruptcy prediction between big banks and mediumbanks.

\begin{tabular}{llrl}
\multicolumn{4}{c}{ Table 4 Comparisson of mean between Big, } \\
\multicolumn{4}{c}{ Medium, and Small } \\
\hline & Big & Medium & Small S-score \\
\hline CA & 12,30 & 12,06 & 16,49 \\
EA & 14,19 & 13,21 & 18,09 \\
CAR & 19,29 & 20,44 & 23,96 \\
NPL & 2,54 & 3,82 & 2,31 \\
CI & 51,28 & 78,96 & 82,11 \\
LA & 64,36 & 64,22 & 59,12 \\
\hline
\end{tabular}

Table 4 shows that small banks have higher Bankometer score compared to big banks and medium banks. This is supported because small banks have higher capital-to-asset (CA) ratio than big banks and medium banks. This ratio is used to measure whether banks have enough capital to support its assets [27]. The higher this ratio the better the performance would be because the assets owned is financed with long term funds. Therefore it can be said that the performance of small banks is better than big banks and medium banks. This is in accordance with the bankometer score that shows small banks having better bankruptcy prediction than big and medium banks. Overall the CA ratioaverage is satisfactory since the result of this study shows that be it big, medium or small banks all banks are above the limit set by IMF which is $4 \%$. It can alsobe seen that the equity to asset (EA) ratio of small banks is higher than big banks and medium banks. This ratio shows that the asset percentage of the company is financed by equity. The higher this ratio is, the lower the company's leverage, which indicates smaller dependency on external party in terms of financing. Therefore, it can be said that small bank's dependency on external party is smaller than big and medium banks. This becomes important since a company's dependency to debt can be an indicator that causes bankruptcy. Overall, be it big, medium or small banks all banks have EA average higher than the limit set by the IMF which is $2 \%$.

Small banks have CAR value higher than big and medium banks. This shows that small banks are more efficient and stable because of its capacity to better fulfill obligation and risks such as credit, operational and other risks. In other words, small banks have better ability to cover risk of loss from its activities and to finance its operational activities [28]. Generally, be it for big, medium or small banks all have CAR average above the minimum limit of $8 \%$ and under the maximum limit of $40 \%$.

Higher ratio of non-performing loan to total loan (NPL) indicates worse bank credit quality, which would result in bigger credit problems for the bank, which would subsequently result in higher probability of bankruptcy. This is due to many non-performing credit, which result in the bank being unable to receive interest payment from the credit and there will also be anincrease in operational costs since collection would beneeded and other costs would be incurred [29]. The result of this study shows that small banks have lower NPL compared to big and medium. From the results of this study it can be said that small banks are able to manage credit better than big banks and medium banks. Overall, average NPL for big, medium and small banks are all above the minimum limit set by the IMF, which is $15 \%$. It can be seen that small banks have the highest

cost to income (CI) average compared to big banks and medium banks. Cost to income is used to evaluate the bank's ability in managing its operational business. This shows that big banks are more efficient in its cost management and resource allocation compared to small and medium banks. The lower the ratio, the better the performance of the company. Loan to asset (LA) ratio is the lowest for small banks, which suggest that small banks are in the most liquid condition. LA of big, medium and small banks are all under the maximum limit set by the IMF which is $65 \%$ which means the companies are all in liquid condition. The higher the LA, the lower the liquidity of the company.

The results of this study suggest that the bigger the 
banks, the lower the bankruptcy prediction score, or in other words the higher the chances for bankruptcy. This study suggests that the smaller the banks the better its condition would be. This is possible because small banks would possibly have smaller leverage, assets arefinanced more using long term fund, and its capital adequacy to cover loss and risks are also better compared to medium banks and big banks. Aside form that small banks also have better credit quality and liquidity compared to big banks and medium banks. This result suggested the more activities done by the banks, there would also be more risks surfacing [30]. This is also related to the allocation of credit since the function of banking is to gather and disburse funding. Banks with bigger size could not make profit from its product due to non performing loans, the high costs, and managerial inefficiencies [31].

The bigger the bank, the more complex it would become and it would also be under more scrutiny and control. This is related to the capital of baking because in order for there to be more supervision, technology is needed and therefore higher cost is required as well. This is related to CAR which is an indicator that evaluates the capital. Companies that are in developing stages would naturally require high fund for its activities and therefore the profit made from operational activities will be used for reinvestmentactivities and not to pay out dividend for shareholders [32]. This would result in negative response from the investors, which could cause the decrease in the company's stock pricing in the stock market. In this case, capitalization is obtained from the price of the stock multiplied by the number of stocks available. Companies with small market capitalization size is still in the developing stages and this is also shown by the cost to income $(\mathrm{CI})$ ratio that shows that the average CIin small banks is higher compared to big or medium banks. Despite higher CI ratio, overall the average bankometer score of small banks turn out to be the best. This suggests that small-sized banks are predicted to be in better condition. The result of this study can be a signal especially for investors when making investment decisions.

Based on the results of this study, this suggests that overall be it big, medium or small banks average scores tend to be above the $70 \%$ score in the bankometer which indicates that all banks are in good condition and is not in the condition where it's predicted to face bankruptcy. Due to that achievement, all banks need to maintain its bankometer S-score since this suggests that the banks are in very good conditions. However, more attention is needed since although all banks are in the range of good condition, but for big, medium and smallbanks they need to put more consideration into its ratios especially its CI ratio, in which all three categories of banks were unable to fulfill its maximum limit. Several other ratios need to also be taken into consideration since although the averages are all above the set limit, but there were also some banks that exceeded the maximum or could not fulfill the minimum limits set by the IMF. Therefore, it's important for the banks to pay more attention to those ratios to prevent bankruptcy. Investors can also take the results of this study into consideration when making investment decisions whereby banks with bigger market capitalization does not always mean that the banks will have better bankruptcy prediction results. On the contrary, according to this study small banks havebetter bankruptcy prediction results, followed by medium banks and big banks in the last place.

\section{CONCLUSION}

Based on the results of this study, it can be concluded that there were differences between the bankruptcy predictions of big, medium and small banks. Significant differences were observed between big and small banks categories and medium and small bank categories. However, there was not significant difference between big banks and medium banks. Small banks have the lowest bankruptcy prediction compared to big and medium banks since it has better CA, EA, CAR, NPL and LA ratio than the other categories. yang

Overall, the results obtained suggest that all three groups of banks have bankometer S-score above the limit of $70 \%$, which means that all banks are in good condition or is not predicted to face bankruptcy. However, despite being in good condition, there are several banks with cost to income (CI) ratio lower than the limit set by the IMF. There were also several companies that exceeded other ratio limits, although in general the average shows to be within the limits set by IMF.

For future studies, researchers can use and compare bankruptcy prediction models. The size of company used can also be developed, for example, using the totalasset of the company, company income or the number of employees. Comparison can also be made using different stock exchange markets around the world.

\section{REFERENCES}

[1] Nova, N., Andi, S.A., and Puti, D.H. (2016). Analisis Kebangkrutan Bank melalui Rentabilitas, Capital dan Bankometer: Studi pada Bank Umum

[2] Indonesia dan Malaysia. Jurnal Ekonomi, Manajemen dan Perbankan, 2(1), 11-16.

[3] Ni Made, P. and Maria, M.M.R. (2013). Prediksi Kebangkrutan dengan Model Grover, Altman ZScore, Springate dan Zmijewski pada Perusahaan Food and Beverage di Bursa Efek Indonesia. EJurnal Akuntansi Universitas Udayana, 5(2), 417-435. 
[4] Vina, N.A and Rivai, A. (2018). Analisis Potensi Kebangkrutan Bank Umum Swasta Nasional Devisa yang Terdaftar di BEI. Jurnal Perbarnas, 3(2), 19-33.

[5] Anita, E., Ubud, S., Mohammad, S.I., and Djumahir. (2013). Financial Performance Analysis of PT. Bank Papua: Application of Cael, Z-Score and Bankometer. Journal of Business and Management, 7(5), 8-16.

[6] Muhammad, Y. (2017). Dampak Indikator Rasio Keuangan terhadap Profitabilitas Bank Umum Syariah di Indonesia. Jurnal Keuangan dan Perbankan, 13(2), 141-151.

[7] Shamanth and Mahes, R. (2016). Assessment of Financial Health of Select Private Sector and Foreign Banks in India: An Application of Bankometer Model. International Journal of Engineering and Management Research, 6(4), 2630 .

[8] Nagmani, M., and Abirami, K. (2017). Performance of Public Sector Banks in India - an Analytical Study. International Journal of Research in Commerce, economics and Management, 7(5), 22-26.

[9] Tri, A. (2018). Tingkat Kebangkrutan dan Karakteristik Perusahaan terhadap Nilai Perusahaan (Sebuah Model : Pendekatan Springate). Jurnal Riset Bisnis, 2(1), 56-69.

[10] Fitria, N., Dewi, S.P.A., and Fadjar, H. (2018). Pengaruh Opinion Shopping dan Audit Tenure terhadap Opini Audit Going Concern dengan Ukuran Perusahaan sebagai Variabel Moderasi. Jurnal Akuntansi dan Sistem Teknologi Informasi, 14(1), 115-124.

[11] Xenia, IS. L. and Johan, T. (2017). Financial Soundness Evaluation of Selected Commercial Banks in Indonesia: An Application of Bankometer Model. Journal of ASEAN Studies on MaritimeIssues, 3(5), 28-39.

[12] Laila, N., and Faris, W. (2017). Financial Distress Prediction Using Bankometer Model on Islamic and Conventional Banks: Evidence from Indonesia. International Journal of Economics and Management, 11(1), 169-181.

[13] Abirami, K. (2018). Financial Soundness of Indian

[23] Predicting Financial Distress in Banking Industry. Jurnal Keuangan dan Perbankan, 22(2), 241256.

[24] Ika, Y. and Rasi, S. (2016). Kointegrasi antara Profitabilitas, Solvabilitas dan Kapitalisasi Pasar. Jurnal EBBANK, 7(1), 23-30.

[25] Khoirunnisa, N.F., Suparti and Tarno. (2016). Permodelan Regresi Spline Truncated Untuk Data Longitudinal (Studi Kasus: Harga Saham Bulanan pada Kelompok Saham Perbankan Periode Januari2009 - Desember 2015. Jurnal Gaussian,
Banking Industry: Bankometer Analysis. International Journal of Applied Research, 4(3), 357-362.

[14] Hayanuddin, S. (2018). Kajian Model Altman ZScore dalam Mendeteksi Potensi Kebangkrutan bank. Jurnal Ecobisma, 5(2), 54-70.

[14 ] Winny, H and Luciana, S.A. (2005). Analisis Rasio Camel terhadap Prediksi Kondisi Bermasalah pada Lembaga Perbankan Perioda 2000-2002. Jurnal Akuntasi and Keuangan, 7(2),131-147.

[15] Debby, L. (2013). Analisis Kebangkrutan Bank terhadap Harga Saham Pada Perusahaan Perbankan yang Terdaftar di Bursa Efek Indonesia. Jurnal Keuangan dan Bisnis, 11(1), 120-144.

[16] Khaled, H., Kuldeep, K., and Adrian, G. (2018). Financial Distress Prediction of Islamic Banks Using Tree-Based Stochastic Techniques. Managerial Finance, 4(6), 1-10.

[17] Franco, P., Carlos, M., and Antonio, P. (2005). Bankruptcy in Banks from Ecuador: Solvency Versus Panic Theories. International Finance Review, 5, 231-247.

[18] Zhang, Y., Lu, B., \& Zheng, H. (2020). Can buzzing bring business? Social interactions, network centrality and sales performance: An empirical study on business-to-business communities. Journal of Business Research, 112, 170-189.

[19] Guglielmo, M. C., Suman, L., and Monomita, N. (2017). The Performance of Banks In the Mena Region During the Global Finance Crisis. Researchin International Business and Finance, 42,583-590.

[20] Chrisna, A.J., I Wayan, S., and Made, S. (2014). Analisis Model Regresi Data Panel Tidak Lengkap Komponen Galat Dua Arah dengan Penduga Feasible Generalized Least Square (FGLS). JurnalMatematika, 4(1), 22-38.

[21] Nan-Kuang, C. (2001). Bank Net Worth, Asset Prices and Economic Activity. Journal of MonetaryEconomics, 48(2), 415-436.

[22] Laely, A.A. (2018). Bankometer Models for

5(3),447-454.

[26] Komang, T.W. (2019). Studi Perbandingan Kinerja Portofolio Saham Berdasarkan Kapitalisasi Pasar Di Bursa Efek Indonesia Dengan Risk Adjusted Return. Jurnal Ilmu Manajemen, 9(1), 75-83.

[27] Anny, W. and Henny, C.R. (2019). Perbedaan Model Ohlson, Model Taffler, Model Springate dalam Memprediksi Financial Distress. Jurnal Akuntansi, 3(2), 141-157.

[28] Muhammad, Z.R. (2017). Financial Soundness 
Evaluation of Selected Commercial Banks in Bangladesh: An Application of Bankometer Model. Research Journal of Finance and Accounting, 8(2), 63-70.

[29] Sugeng, H. (2016). Determinan Permodalan Bank Melalui Profitabilitas, Risiko, Ukuran Perusahaan, Efisiensi dan Struktur Aktiva. JurnalEkonomi dan Bisnis, 19(1), 117-136.

[30] Liviawati., Jeni, W., and Gusmarila, E. K., (2019). Faktor-Faktor yang Mempengaruhi Efesiensi Perbankan Studi Pada Bank Swasta yang Terdaftar di Bursa Efek Indonesia. Jurnal AkuntansiKompetif, 2(3), 95-101.

[31] Dani, S. and Wiwin, P.R. (2017). Pengaruh Rasio Keuangan dan Ukuran PerusahaanTerhadap
Financial Distress (Studi Empiris pada Perusahaan Food and Beverage di Bursa Efek Indonesia). Jurnal Akuntansi dan Keuangan, 1(2), $1-10$.

[32] A A Yogi, P. and I Wayan, R. (2013). Analisis Pengaruh CAR, BOPO, LDR dan Ukuran Perusahaan terhadap Profitabilitas Bank yang Terdaftar di BEI. E-journal Akuntansi Universitas Udayana, 4(1), 230-245.

[33] I Nyoman, S. and I Ketut, M. (2017). Pengaruh Leverage, Ukuran Perusahaan, dan Profitabilitas terhadap Nilai Perusahaan Pada Perusahaan Properti. E-Jurnal Manajemen Unud, 6(3), 1248-1277 